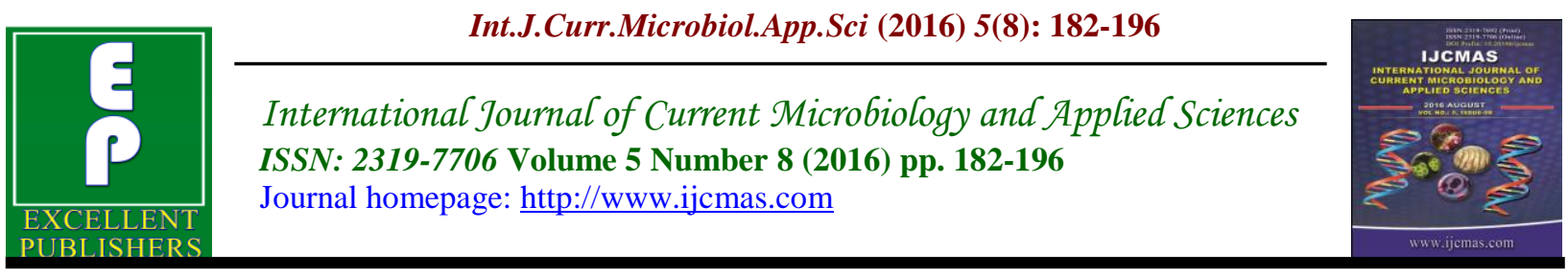

Original Research Article

http://dx.doi.org/10.20546/ijcmas.2016.508.020

\title{
Hypericum sinaicum L. in Vitro Regeneration and Analysis of Hypericin Content
}

\author{
Heba D. Khlifa ${ }^{1}$, Ibrahim A. Ibrahim ${ }^{2}$, M. Bekhit ${ }^{2}$, M. Szkop ${ }^{3}$ and H.S. Taha ${ }^{1}$ * \\ ${ }^{1}$ Plant Biotechnology Department, National Research Centre (NRC), Dokki, P.O.12622Cairo \\ Egypt ${ }^{2}$ Plant Biotechnology Dept., Genetic Engineering Institute (GEBRI), \\ University of Sadat City, Egypt \\ ${ }^{3}$ Biochemistry Department, Faculty of Agriculture and Biology, Warsaw University of \\ Life Sciences (SGGW), Poland \\ *Corresponding author
}

\section{Keywords}

Hypericum

sinaicum,

in vitro

propagation,

regeneration,

multiplication, hypericin.

\section{Article Info}

Accepted:

12 July 2016

Available Online:

10 August 2016

\section{A B S T R A C T}

The present study aimed to use plant biotechnology techniques and biochemical analyses to achieve promising procedures for regenerated shootlets of Hypericum sinaicum L. via direct/ indirect regeneration. So and related to this concern, this investigation was carried to examine the effect of different explant types and culture conditions, with emphasis on the type and concentrations of plant growth regulators (PGRs) in culture media on shootlets regeneration and prolonged maintenance of in vitro material. The results showed that, direct/indirect shoot formation were induced by all levels of PGRs but the optimum medium for direct shootlets induction and multiplication was MS supplemented with $0.1 \mathrm{mg} / \mathrm{l} \mathrm{NAA}$ combination with $1 \mathrm{mg} / \mathrm{l}$ BA compared with other supplementations. The maximum number of direct shootlets regeneration (24 shootlets per explant) was recorded with nodal explant cultured on MS medium supplemented with 0.1 NAA mg/l plus $1 \mathrm{mg} / 1 \mathrm{BA}$ under light condition. While the maximum number of indirect shootlets regeneration (14 shootlets per callus) was recorded with the same previous explant cultured on MS medium augmented with $0.5 \mathrm{mg} / \mathrm{l} \mathrm{TDZ}$ and $0.05 \mathrm{mg} / \mathrm{l} \mathrm{NAA}$ under light and darkness condition. In this regard, after regeneration was developed, the vegetative growth dynamics patterns were estimated through the following parameters; number of shoots/one piece of callus, length of shoot $(\mathrm{cm})$, fresh weight ( $\mathrm{g} / \mathrm{jar})$, dry weight ( $\mathrm{g} / \mathrm{jar})$, dry matter content $(\%)$. In addition, determination of hypericin component in in vitro germinated plantlet(s) as control and regenerated shoot was estimated using high performance liquid chromatography (HPLC) techniques. The highest value of hypericin contents $84.70,72.18 \mu \mathrm{g} / \mathrm{g}$ dry weights were estimated in direct shoots regeneration derived from nodal and root explants on MS supplemented with $0.1 \mathrm{mg} / \mathrm{l} \mathrm{NAA}+1 \mathrm{mg} / \mathrm{l} \mathrm{BA}$ at light condition.

\section{Introduction}

Medicinal vegetation is a therapeutic resource much utilized by the traditional population of the world especially for the health care. Worldwide interest in the use of medicinal plants is now increasing Okigbo 
et al., (2009). In modern medicine, a large proportion of drugs were isolated from plants. Similarly, from synthetically modified compound extracted from natural origin. Moreover, in the form of natural products or as functional foods, medicinal plants and their extracts offer a substitute for specially targeted drugs in the treatment and protection against many diseases Lahlou (2013).

For decades, Hypericum spp are known as traditional medicinal plant. It is used medicinally for a range of many purposes in folk medicine. The plant has many magic and attracted attentions for its woundhealing, diuretic and sedative properties. Also, it has been used to treat traumas and neurological disorders (Butterweek, 2003). However, the plant is still under intensive investigation for its anti-inflammatory, antibacterial, antiviral, and antitumoral properties Medina et al., (2006). Moreover, it has been suggested for the treatment of substance dependence (Uzbay, 2008) and antitumoral agent (Karioti and Bilia, 2010). Therefore, study of their pharmacological effects and the responsible compounds for these effects continues. One of the most important Egyptian medicinal plants is Hypericum sinaicum L. It belongs to the Clusiaceae family. The herbaceous perennial $H$. sinaicum is a highly variable species and native to Egypt (Khafagi and omar, 2012). The plant grows typically on dry meadows, sunny hillsides, and field clearings, along roadsides and in other similar habitats. The genus is of great economical and medicinal importance for containing of phytochemical constituents (Messina, 2006).

Naphthodianthrones such as hypericin and phloroglucinols are the interest and focused in these plants (Karioti and Bilia, 2010). Many attempts were made to generate and producing maximum concentrations of these bioactive compounds in the plants or their cell cultures. The methods of analytical chemistry of these target compounds become of critical importance. However, hypericin has also been found in some fungi and animal species Kusari et al., (2009). Hypericins are most accumulated in the petals and stamens of flowers, but those are also found in leaves at high amounts ( 0.03 to 0.3 percent), and 1 up to 14 percent in flower buds Zobayed et al., (2006). Naturally, hypericins are concentrated and accumulated in the dark glands of Hypericum plant. Furthers, these glands have also been suggested to be the sites of their biosynthesis. The concentrated of hypericins in these glandular avoids the potential toxicity of these compounds to plant tissues. However, the important and function of hypericins in Hypericum species is still not clear, it has been suggested that they have a defensive role against herbivores and plant pathogens (Bruni and Sacchetti, 2009).

Plant tissue culture technique considered an important tool for the production of chemicals and pharmaceuticals compounds. Further, plant biotechnology technology was applied to increase of natural products for medicinal purposes to overcome the low product yields and supply concerns of plant harvesting. Multiplication or in vitro regeneration of rare medicinal plants using biotechnological is urgent and important (Tripathi and Tripathi, 2003). Root explants of St. John's wort are superior for in vitro shoot regeneration (Zobayed and Saxena, 2003). While, flowers, petals and sepals explants have been used in some plant species as a source of explants for plant regeneration (Debnath, 2005), (Wu and Zhang, 2008). Further, using of in vitro culture techniques has been reported as an alternative system for production of plant 
material in the pharmaceutical industry at the level of commercial scale to satisfy the growing demand of natural products as well as to obtain less variable preparations. For this target purpose, plant cell and suspension culture technique has been successfully applied to produce large quantities and qualitative of secondary metabolites from a wide and many plants Taniguchi et al., (2002).

Secondary products play important protective and defensive roles in plants and their production can be stimulated reliably in vitro by compounds and conditions that induce stress responses. Thus, plant tissue culture can be used to enhance in vitro secondary metabolite accumulation from tissue cultures by modifying culture conditions (Ramachandra and Ravishankar, 2002). The factors influencing biochemical production in plant tissue culture include genotype, developmental stage of explants, and culture environment such as culture media, temperature and light. Furthermore the relationship between biosynthesis of hypericin compounds and in vitro development of differentiated structures in Hypericum plants has also been investigated (Coste et al., 2011), (Palmer and Keller, 2011).

Despite the fact that, Hypericam sinaicum L. is one of a very valuable medicinal plant in Egypt, but there is no report on the direct/indirect regeneration and hypericin content of regenerated shootlets of $H$. sinaicum.

\section{Materials and Methods}

\section{Plant materials}

Source of $H$. sinaicum seeds was kindly provided by Dr. Hussein Taha, Plant Biotechnology Department National Research Centre, Cairo, Egypt.
Establishment of sterilized Hypericum sinaicum L. seedlings

Seeds of $H$. sinaicum L. were surface sterilized by immersing in $70 \%$ ethanol for $1 \mathrm{~min}$, followed by three washes with sterile distilled water. Further, the seeds were immersed in $20 \%$ of commercial bleach Clorox (5.25 \% Sodium hypochlorite) solution for $10 \mathrm{~min}$. After the bleach solution was discarded, seeds were rinsed three times with sterile distilled water. Whereas sterilized seeds were germinated aseptically on $50 \mathrm{ml}$ of three types of full strength of nutrient solidified basal medium either MS salts ( Murashig and Skoog, 1962) LS salts (Linsmaier and Skoog, 1965) or B5 salts (Gamborg et al., 1968) in $250 \mathrm{ml}$ glass jars for 20-30 days. Ten replicates, each of 10 seeds per jar were used. Agar was added prior to autoclaving at $1.2 \mathrm{~kg} / \mathrm{cm}^{2}$ for 20 min. The $\mathrm{pH}$ of the medium was adjusted to 5.8 by the addition of $0.1 \mathrm{~N} \mathrm{HCL}$ or $0.1 \mathrm{~N}$ $\mathrm{KOH}$. Cultured jars were incubated in a growth chamber at $26 \pm 1^{\circ} \mathrm{C}$ and exposed to $16 \mathrm{~h} /$ day photoperiod under standard cool white fluorescent tubes at light intensity 20$25 \mu \mathrm{mol} \mathrm{m} \mathrm{s}^{-1}$.

\section{Shoots induction and multiplication}

Under aseptic conditions, the nodal segments and root explants were excised from three weeks old $H$. sinaicum seedling. Explants were culture onto composition of MS media with supplement of different concentrations of auxins and cytokinins as follow:-

$$
\begin{array}{ll}
\text { 1- } & \mathrm{MS}+0.5 \mathrm{mg} / \mathrm{l} \mathrm{BA} \\
\text { 2- } & \mathrm{MS}+0.5 \mathrm{mg} / \mathrm{l} \mathrm{TDZ} \\
\text { 3- } & \mathrm{MS}+0.05 \mathrm{mg} / \mathrm{l} \mathrm{NAA} \\
\text { 4- } & \mathrm{MS}+0.1 \mathrm{mg} / \mathrm{l} \mathrm{NAA}+1 \mathrm{mg} / \mathrm{l} \mathrm{BA} \\
\text { 5- } & \mathrm{MS}+0.5 \mathrm{mg} / \mathrm{l} \mathrm{TDZ}+0.05 \mathrm{mg} / \mathrm{l} \\
& \mathrm{NAA} \\
\text { 6- } & \mathrm{MS}+0.5 \mathrm{mg} / \mathrm{l} \mathrm{BA}+0.5 \mathrm{mg} / \mathrm{TDZ}+ \\
& 0.05 \mathrm{mg} / \mathrm{l} \mathrm{NAA}
\end{array}
$$


All cultures were incubated under $26 \pm 1{ }^{\circ} \mathrm{C}$ in a growth chamber with a daily16-h under $16 \mathrm{~h} /$ day photoperiod under standard cool white fluorescent tubes at light intensity 20$25 \mu \mathrm{mol} \mathrm{m} \mathrm{m}^{-2} \mathrm{~s}^{-1}$ in light, and darkness condition. The experiment was consisted of ten jars per treatment. After 30 days shoots regeneration, and number of shoots per explant were quantified.

\section{Shoot elongation}

Performed shootlets (approximately $1.5 \mathrm{~cm}$ height) were cultured on MS medium supplemented with three different concentrations of kin $(0.1,0.5$ and $1 \mathrm{mg} / \mathrm{l})$ for elongation. Four shoots were cultured in each jar and incubated at $26 \pm 1{ }^{\circ} \mathrm{C}$ in a growth room with a 16-h under $16 \mathrm{~h} /$ day photoperiod under standard cool white fluorescent tubes at light intensity 20-25 $\mu \mathrm{mol} \mathrm{m} \mathrm{m}^{-2} \mathrm{~s}^{-1}$ and in dark for 20 days. The average of shoot height $(\mathrm{cm})$ was evaluated.

\section{Rooting of shoot}

After shoot elongation, one cluster of elongated shoots $(3 \mathrm{~cm})$ was placed on half salt strength of MS medium containing 30 $\mathrm{g} / \mathrm{l}$ sucrose and two different types of auxins IAA and IBA at three concentrations $(1,5$ and $10 \mathrm{mg} / \mathrm{l}$ ) to induce rooting and incubated at $26 \pm 1^{\circ} \mathrm{C}$ in a growth room with a 16 -h under $16 \mathrm{~h} /$ day photoperiod under standard cool white fluorescent tubes at light intensity $20-25 \mu \mathrm{mol} \mathrm{m} \mathrm{m}^{-2} \mathrm{~s}^{-1} \mathrm{or} /$ and in dark for 30 days. The following parameters were evaluated at the end of this experiment (30 days):

1- Number of formed roots

2- Root length $(\mathrm{cm})$

\section{Vegetative growth dynamics}

The vegetative growth dynamics patterns for the regenerated shoots derived from nodal segment explants were estimated through the following parameters:

1- Number of shoots

2- Length of shoot $(\mathrm{cm})$

3- Fresh weight (g)

4- Dry weight (g)

The parameters were recorded during 5 weeks of cultivation

\section{Statistics analysis}

Statistical analysis was done using SPSS 17 for windows and the values were expressed as mean \pm S.D. The statistical significance of differences between the means was analyzed using one-way analysis of variance (ANOVA) followed by Duncan's test for comparison between different treatment. Statistical significance was set at $\mathrm{P} \leq 0.05$.

\section{Sample preparation for chemical analysis}

Direct/indirect regenerated shoot from nodal and root explants were dried on a filter paper to wipe away the agar and excised water. As well as in vitro 1.5 month old germinated plants of $H$. sinaicum growing in the lab on free MS medium without growth regulators were used as control treatment. All samples were dried in oven for 3 days at $50^{\circ} \mathrm{C}$ and grounded with a coffee grinder. All samples were extracted after dryness and analyzed by HPLC to detect hypericin content.

\section{HPLC Analysis of hypericin}

This part of study was carried out in Polish Academy of Sciences (Department Of Biochemistry- Faculty of Agriculture and Biology- Warsaw University of Life Sciences-SGGW) e-mail: kbioch@sggw.pl

Chromatographic Conditions: The HPLC system was composed of a binary pump 
(Model 1525, Waters Corporation, Milford, MA, USA), a fluorimetric detector (Model 474, Waters; $\lambda$ ex $=236 \mathrm{~nm} / \lambda \mathrm{em}=592 \mathrm{~nm}$ ), an autosampler (Model 717plus, Waters) and a personal computer with Breeze data acquisition and integration software (Waters).

Chromatographic separations were performed at ambient temperature on a $\mathrm{C} 8$ column (Symmetry 4.6 x $150 \mathrm{~mm}, 5 \mu \mathrm{m}$, Waters) fitted with a C8 guard column (Symmetry 3.9 × $20 \mathrm{~mm}, 5 \mu \mathrm{m}$, Waters) using gradient eluents.

Mobile phase Eluents A consisted of 60 $\mathrm{mM}$ phosphate buffer $\mathrm{pH} 6.8$ and eluent B consisted of $80 \%: 20 \%(\mathrm{v} / \mathrm{v})$ acetonitrile: $\mathrm{H}_{2} \mathrm{O}$. The mobile phase started with eluent A: eluent B at 80: $20 \%$, gradient programs of mobile phase (concentrations and run time) are used as shown in Table (1). The total run time was $100 \mathrm{~min}$. The flow rate of mobile phase was $1 \mathrm{ml} / \mathrm{min}$. the injection volumes were $20 \mu 1$.

\section{Results and Discussion}

\section{In-vitro seeds germination}

Full salt strengths of basal MS, LS and $\mathrm{B}_{5}$ nutrient media were investigated for $H$. sinaicum seeds germination under aseptic conditions. Cultures were incubated for 28 days at $26 \pm 1{ }^{\circ} \mathrm{C}$ under light illumination (16/8h).

The total numbers of germinated seeds were recorded after 28 days of cultivation. Data in Table (2) showed that, the germination percentages whereas the highest percentages of seeds germination ( $84 \%$ ) was recorded with full salt strength of MS media compared other used nutrient media.
Direct and Indirect regeneration of $H$. sinaicum

Nodal and root explants were maintained on MS medium amended with various types within different concentrations of PGRs. In additional, an equal weights of the obtained calli from nodal and root explants were recultured on the same previously composition of MS media. All cultures were incubated under light and dark conditions. As shown in Table (3) and Figure (1A) the maximum number of direct shootlets regeneration (24 shootlets /explant) was recorded with nodal explant cultured on MS supplemented with 0.1 NAA $\mathrm{mg} / \mathrm{l}$ plus $1 \mathrm{mg} / \mathrm{l} \mathrm{BA}$ under light condition, while nodal explant recorded (15 shootlets/explant) under dark condition. However, the lowest number of direct shootlets regeneration (3 shootlets/explant) was recorded with root explants cultured on medium of MS augmented by BA at 0.5 $\mathrm{mg} / \mathrm{l}$ and incubated under dark condition.

On the other hand, the maximum number of indirect shootlets regeneration (14 shootlets /callus) was recorded with nodal explants placed on MS medium fortified with TDZ at $0.5 \mathrm{mg} / \mathrm{l}$ and NAA at $0.05 \mathrm{mg} / \mathrm{l}$ under light and darkness condition in Figure (1B), however lowest number of indirect shootlets regeneration (1 shootlets/callus) was observed with root explants cultured on modified MS medium supplemented with $0.5 \mathrm{mg} / \mathrm{l} \mathrm{BA}$ and incubated under dark condition.

\section{Multiplication of $\boldsymbol{H}$. sinaicum shootlets}

An equal number of shootlets (cluster) obtained from direct or indirect regeneration induced from nodal or root explants were subcultured twice every 30 days on modified MS medium with $0.1 \mathrm{mg} / \mathrm{l}$ NAA combined with $1 \mathrm{mg} / \mathrm{l}$ BA for increasing number of shoots. All cultures were incubated under 
light and dark conditions. The best results (uncounted amount of shoots) were obtained from culturing of shootlets clusters induced from nodal explants compared with root explants and incubated under light condition (Fig. 2).

\section{Shoot elongation}

In this experiment approximately $1.5 \mathrm{~cm}$ height of micro-shootlets, that regenerated from direct or indirect shootlets regeneration were placed on MS medium incorporated with $0,0.1,0.5$ or $1 \mathrm{mg} / \mathrm{l} \mathrm{kin}$ and incubated under light and dark conditions at $26 \pm 1{ }^{\circ} \mathrm{C}$. As shown in Table (4), the highest shoot length $9.32 \mathrm{~cm}$ and $5.44 \mathrm{~cm}$ were recorded with supplementation of MS medium with 1 $\mathrm{mg} / \mathrm{l} \mathrm{kin}$ and incubated under light and dark conditions, respectively.

\section{Rooting of shoot}

For rooting, the elongated shoots in cluster were individually subcultured using MS salts medium fortified with 1 and $5 \mathrm{mg} / \mathrm{l}$ of IAA or IBA and incubated under light and dark condition. The maximum numbers or rootlets formation/cluster were recorded with MS medium supplemented with $5 \mathrm{mg} / \mathrm{l}$ IBA or $5 \mathrm{mg} / \mathrm{l}$ IAA, respectively. While, the longest root formation were recorded with MS medium augmented with IBA $(5 \mathrm{mg} / \mathrm{l})$ and incubated under light as shown in Fig. (3).

\section{Vegetative growth dynamics}

The vegetative growth dynamics patterns of shootlets were performed by number of shootlets/ cluster, length of shoots $(\mathrm{cm})$, shootlets fresh and weights (g/jar), and shootlets dry matter content (\%) were recorded during 5 weeks of cultivation. The maximum number of shootlets per cluster were (14 and 4 shootlets/cluster) induced from nodal and root explants, respectively at the end of the $5^{\text {th }}$ week of cultivation. Furthermore, the longest shoots (12.5 and $3.8 \mathrm{~cm}$ ) were measured at the end of the $5^{\text {th }}$ week, with derived shoots from nodal and subsequently root explants, respectively. The highest fresh and dry weights were estimated at the end of the $3^{\text {rd }}$ week. Also the results showed the highest shoot growth rate $(0.273 \mathrm{~g} / \mathrm{day})$ was recorded for shoots derived from nodal explant at the $3^{\text {rd }}$ week of cultivation (Fig. 4). While, root explants was recorded $(0.179 \mathrm{~g} /$ day $)$ at the end of the $3^{\text {rd }}$ week of cultivation.

\section{Hypericin analysis}

The relationship between the peak size, the amount of hypericin expressed as as $\mu \mathrm{g} / \mathrm{gm}$ dry weight were tested and compared to hypericin standard curve (Fig. 6). The linearity of a method was tested for the concentrations from $0.5 \mathrm{mg}$ of hypericin/ $\mathrm{ml}$. the equation of a straight line was $y=a x+b$, the regression coefficient $\mathrm{r}=0.9995$ as shown in Figs. (5).

Hypericin was extracted from control, which was 1.5 month old seedlings in the lab and direct/ indirect regeneration samples and analyzed with HPLC. Total hypericin content expressed as $\mu \mathrm{g} /$ gm dry weights were represented in Table (5). The data showed that indirect shootlets regeneration extract produced from nodal and root explants gave higher hypericin content as $\mu \mathrm{g} / \mathrm{gm}$ dry weight compare to control and other used extracts. Hypericin contents in indirect shootlets regeneration extract derived from nodal explant on MS medium supplemented with $0.5 \mathrm{mg} / \mathrm{l} \mathrm{TDZ}$ and 0.05 $\mathrm{mg} / \mathrm{l}$ NAA at light condition was produced $84.70 \mu \mathrm{g} / \mathrm{g}$ dry weights compared to 72.18 $\mu \mathrm{g} / \mathrm{g}$ dry weights in root explants on the same previous conditions as shown in Figure (7). in vitro derived plantlets (control) gave 
$32.99 \mu \mathrm{g} / \mathrm{gm}$ dry weight while direct shootlets regeneration from nodal and root explants cultured on MS fortified with 0.1 $\mathrm{mg} / \mathrm{l} \mathrm{NAA}+1 \mathrm{mg} / \mathrm{l} \mathrm{BA}$ at light condition were recorded $31.58,13.66 \mu \mathrm{g} / \mathrm{g}$ dry weight, respectively as shown in Table (5).

Regulating of growth and development in plant tissue culture mainly depends on plant growth regulators. Auxins and cytokinins are the two classes of growth regulators generally required and most commonly used in plant tissue culture. The most commonly used synthetic auxins are 2, 4dichlorophenoxyacetic acid (2, 4-D) and 1naphthaleneacetic acid (NAA), which influence cell growth expansion and organogenesis. Indole-3-butyric acid (IBA) is a natural auxin commonly used in plant tissue culture, which is broken down in media several days after application. The most commonly used synthetic cytokinins are kinetin (Kin) and 6-benzylaminopurine or benzyladenine (BA), which interact with auxins and stimulate cell division. Thidiazuron (TDZ) is another growth regulator which has cytokinin activity for shoot induction George et al., (2008).

Shoot regeneration of plantlets can be increase by increasing the ratio of cytokinin to auxin. However, a high ratio of auxin to cytokinin promotes of in vitro root regeneration (Skoog and Miller, 1957). While, a latter ratio can induce shoot formation in various plant species. Mainly the role of cytokinin in shoot regeneration may be enhanced auxin accumulation in meristematic sites where shoots are initiated (Kakani and Peng, 2009). Plant regeneration from cultured explants occurs most likely through either directly or indirectly through callus phase Parrott et al., (1992). There are many reports on regeneration in Hypericum spp. through organogenesis phase using leaves, nodal, hypocotyl and root segments
(Wojcik and Podstolski, 2007; Franklin and Dias, 2005). The interaction between BA and NAA affected transition of callus to regeneration pathway. This interaction plays a key role in regeneration through indirect organogenesis pathway these data matching with obtained results. Whereas our results finding that, the maximum number of direct shootlets regeneration ( 24 shootlets /explant) was recorded with nodal explant cultured on MS supplemented with 0.1 NAA mg/l plus $1 \mathrm{mg} / \mathrm{l} \mathrm{BA}$ under light condition also that is in agreement with (Santarem and Astaria 2003), (Pasque et al., 2008) who observed organogenesis in calli tissue on medium supplemented with plant growth regulators such as BA, NAA and 2,4-D either alone or in combination. Direct organogenesis of $H$. perforatum using TDZ observed by Murch et al., (2000) this observation was differs slightly with our result whereas the results. The maximum number of indirect shootlets regeneration (14 shootlets /callus) was recorded with nodal explant cultured on MS medium containing $0.5 \mathrm{mg} / \mathrm{l} \mathrm{TDZ}$ and 0.05 mg/l NAA. TDZ was become of a potent biological-regulator for in vitro morphogenesis Carvalho (2004) and regeneration. Moreover, it is enhanced organogenesis in several plants Johnes (2007).

On the other hand, the influences of PGRs such as auxins and cytokinins on shootlets multiplication and propagation have been reported in many Hypericum species. The maximum number of shootlets regeneration was recorded in $H$. foliosum on nutrient media augmented with BA and NAA (Moura, 1998). Similar records were displayed for $H$. canariensis (Mederos, 1991). These data were in identical with our results where the results indicated that, uncounted number of shoot were obtained from culturing of shootlets clusters induced from nodal explants on MS medium 
contained $0.1 \mathrm{mg} / \mathrm{l} \mathrm{NAA}$ and $1 \mathrm{mg} / \mathrm{l} \mathrm{BA}$.

Rooting were achieved at the ratio of $100 \%$ by culturing of individual or separated clusters of shootlets on free PGRs of MS medium augmented with IBA at $1 \mathrm{mg} / \mathrm{l}$. The obtained results were in agreed to reports signaled to indicating a requirement for auxin for high frequency rooting of St. John's wort shootlets (Pretto and Santarem, 2000; Franklin and Dias, 2006). In addition, our finding result was in agreement with Ayan et al., (2005) who reported that shootlets of $H$. perforatum were rooted on MS medium fortified with IBA at $1 \mathrm{mg} / \mathrm{l}$.

As well as in our study, the obtained results showed the highest shoot growth rate $(0.273$ $\mathrm{gm} /$ day) was recorded for shoots derived from nodal explant at the $3^{\text {rd }}$ week of cultivation. However, growth rate of shoots derived from root explants was $(0.179$ gm/day) at the end of the $3^{\text {rd }}$ week of cultivation. According to George et al., (2008) who reported that different parameters that can be used to measure growth (e.g. cell number, cell dry weight, total DNA content) an S-shaped growth curve can be obtained. The S-shaped growth curve include a lag phase in which cells prepare to divide, a period of exponential growth in which cell division is maximal, a period of linear growth in which division slows down and cells enlarge, a period of decelerating growth and stationary or nogrowth period in which the number and size of cells is constant.

Table.1 Gradient program of mobile phase

\begin{tabular}{|c|c|c|}
\hline Time [min] & Eluent A (\%)* & Eluent B (\%) $* *$ \\
\hline 0 & 80 & 20 \\
\hline 18 & 0 & 100 \\
\hline 25 & 0 & 100 \\
\hline 27 & 80 & 20 \\
\hline 30 & 80 & 20 \\
\hline
\end{tabular}

+1 additional minute of column flushing with A: B 80\%: $20 \%$ before injection

Where: *Eluent A was $60 \mathrm{mM}$ phosphate buffer pH 6.8 ; **Eluent B was $80 \%$ acetonitrile: $20 \% \mathrm{H}_{2} \mathrm{O}$.

Table.2 Effect of different nutrient media on percentage of in vitro H. sinaicum seeds germination

\begin{tabular}{|c|c|}
\hline Nutrient media & Germination (\%) \\
\hline MS & $84 \pm 0.33^{\mathrm{A}}$ \\
\hline LS & $60 \pm 0.57^{\mathrm{B}}$ \\
\hline $\mathbf{B}_{\mathbf{5}}$ & $64 \pm 0.45^{\mathrm{B}}$ \\
\hline LSD $_{\mathbf{0 . 0 5}}$ & 1.435 \\
\hline
\end{tabular}

Each value is the average of 10 replicates \pm Standard error.

Average values between the columns followed by the same letters were not significantly differed at the level of $5 \%$. 
Table.3 Effect of MS medium modified with different PGRs on direct/indirect shootlets regeneration from nodal and root explants of $H$. sinaicum after 30 days of culturing and incubation under light $(16 / 8 \mathrm{~h})$ or dark conditions at $26 \pm 1^{\circ} \mathrm{C}$

\begin{tabular}{|c|c|c|c|c|c|c|c|c|c|}
\hline \multirow{3}{*}{ No } & \multirow{3}{*}{$\begin{array}{l}\text { MS- supplemented with } \\
\text { different growth } \\
\text { regulators (mg/l) }\end{array}$} & \multicolumn{4}{|c|}{ Direct shoot number/ explant } & \multicolumn{4}{|c|}{ Indirect shoot number/ explants } \\
\hline & & \multicolumn{2}{|c|}{ Light } & \multicolumn{2}{|c|}{ Dark } & \multicolumn{2}{|c|}{ Light } & \multicolumn{2}{|c|}{ Dark } \\
\hline & & $\begin{array}{c}\text { nodal } \\
\text { explant }\end{array}$ & $\begin{array}{c}\text { Root } \\
\text { Explant }\end{array}$ & $\begin{array}{c}\text { nodal } \\
\text { segments }\end{array}$ & $\begin{array}{c}\text { Root } \\
\text { explant }\end{array}$ & $\begin{array}{c}\text { nodal } \\
\text { explant }\end{array}$ & $\begin{array}{c}\text { Root } \\
\text { Explant }\end{array}$ & $\begin{array}{c}\text { nodal } \\
\text { segments }\end{array}$ & $\begin{array}{c}\text { Root } \\
\text { explant }\end{array}$ \\
\hline 1 & $0.5 \mathrm{mg} / \mathrm{l} \mathrm{BA}$ & $7 \pm 0.24$ & $5 \pm 0.31$ & $5 \pm 0.0$ & $3 \pm 0,24$ & $5 \pm 0.0$ & $3 \pm 0.24$ & $5 \pm 0.0$ & $1 \pm 0.20$ \\
\hline 3 & $0.5 \mathrm{mg} / \mathrm{l} \mathrm{TDZ}$ & $14 \pm 0.2$ & $10 \pm 0.31$ & $9 \pm 0.48$ & $7 \pm 0.4$ & $12 \pm 0.25$ & $6 \pm 0.37$ & $9 \pm 0.48$ & $6 \pm 0.37$ \\
\hline 4 & $0.05 \mathrm{mg} / \mathrm{l} \mathrm{NAA}$ & $9 \pm 0.37$ & $7 \pm 0.24$ & $8 \pm 0.34$ & $7 \pm 0.24$ & $7 \pm 0.24$ & $6 \pm 0.20$ & $8 \pm 0.24$ & $5 \pm 0.0$ \\
\hline 6 & $\begin{array}{l}\text { 0.1 mg/l NAA + } 1 \mathrm{mg} / \mathrm{l} \\
\text { BA }\end{array}$ & $24 \pm 0.2$ & $13 \pm 0.24$ & $15 \pm 0.31$ & $10 \pm 0.31$ & $9 \pm 0.20$ & $7 \pm 0.40$ & $10 \pm 0.31$ & $7 \pm 0.25$ \\
\hline 7 & $\begin{array}{l}0.5 \mathrm{mg} / \mathrm{l} \mathrm{NAA}+0.05 \mathrm{mg} / \mathrm{l} \\
\text { TDZ }\end{array}$ & $14 \pm 0.44$ & $11 \pm 0.37$ & $8 \pm 0.24$ & $9 \pm 0.37$ & $14 \pm 0.20$ & $11 \pm 0.2$ & $14 \pm 0.2$ & $9 \pm 0.37$ \\
\hline 9 & $\begin{array}{l}0.05 \mathrm{mg} / \mathrm{l} \mathrm{NAA}+0.5 \mathrm{mg} / \mathrm{l} \\
\text { TDZ + 0.5 mg/l BA }\end{array}$ & $22 \pm 0.24$ & $13 \pm 0.24$ & $14 \pm 0.20$ & $10 \pm 0.0$ & $12 \pm 0.4$ & $9 \pm 0.20$ & $8 \pm 0.24$ & $6 \pm 0.37$ \\
\hline
\end{tabular}

Each value is the average of 5 replicates (jars) \pm SE.

Table.4 Effects of kin at different concentrations on shoot length $(\mathrm{cm})$ of H. sinaicum

\begin{tabular}{|c|c|c|}
\hline \multirow{2}{*}{ Concentration of kin $(\mathbf{m g} / \mathbf{l})$} & \multicolumn{2}{|c|}{ shoots length $(\mathbf{c m})$} \\
\cline { 2 - 3 } & Light & Dark \\
\hline 0 & $2.58 \pm 0.36$ & $1.8 \pm 0.18$ \\
\hline 0.1 & $4.84 \pm 0.24$ & $2.98 \pm 0.26$ \\
\hline 0.5 & $7.34 \pm 0.28$ & $4.98 \pm 0.14$ \\
\hline 1 & $9.32 \pm 0.28$ & $5.44 \pm 0.23$ \\
\hline
\end{tabular}

Each value is the average of 5replicates \pm Standard error.

Table.5 HPLC analysis of hypericin ( $\mu \mathrm{g} / \mathrm{g}$ dry weight) content in control, and regenerated tissues derived from nodal or root segments of $H$. sinaicum cultured on different modified MS media

\begin{tabular}{|l|l|c|c|c|c|c|}
\hline \multicolumn{1}{|c|}{ Sample } & \multicolumn{1}{|c|}{ Treatment } & Peaks area & $\boldsymbol{\mu g} /$ injected & $\boldsymbol{\mu g} / \boldsymbol{\mu l}$ & $\begin{array}{c}\text { Sample Dry } \\
\text { Weigth }(\mathbf{g})\end{array}$ & $\boldsymbol{\mu g} / \mathbf{g}$ \\
\hline $\begin{array}{l}\text { Control } \\
\text { seedling }\end{array}$ & $\begin{array}{l}\text { Full salt strength MS } \\
\text { medium }\end{array}$ & 1175 & 0.165 & 8.258 & 0.2503 & 32.99 \\
\hline DSh-NS & MS + 0.1 mg/l NAA + & 9891 & 1.406 & 70.337 & 3.34 & 31.58 \\
\hline DSh-R & $\mathbf{1 m g / l ~ B A ~}$ & 221 & 0.029 & 1.463 & 0.2143 & 13.66 \\
\hline ISh-NS & MS + 0.5 mg/l TDZ+ 0.05 & 34509 & 4.912 & 245.641 & 2.9 & 84.70 \\
\cline { 3 - 7 } ISh-R & mg/l NAA & 23426 & 3.334 & 166.739 & 4.62 & 72.18 \\
\hline
\end{tabular}

Whereas:-

Control: in vitro derived plantlets

DSh-NS: Direct shootlets derived from Nodal segment

ISh-NS: Indirect shootlets derived from Nodal segment

DSh-R: Direct shootlets derived from root explant

ISh-R: Direct shootlets derived from root explant 
Fig.1 Effect of (A) MS medium fortified with $0.1 \mathrm{mg} / 1 \mathrm{NAA}+1 \mathrm{mg} / \mathrm{l} \mathrm{BA}$ on direct shootlets regeneration and multiplication from nodal explants at light and dark condition, respectively. (B) MS medium fortified with $0.5 \mathrm{mg} / \mathrm{l} \mathrm{TDZ}+0.05 \mathrm{mg} / \mathrm{l} \mathrm{NAA}$ on indirect shootlets regeneration from nodal explants under light and dark condition, respectively.
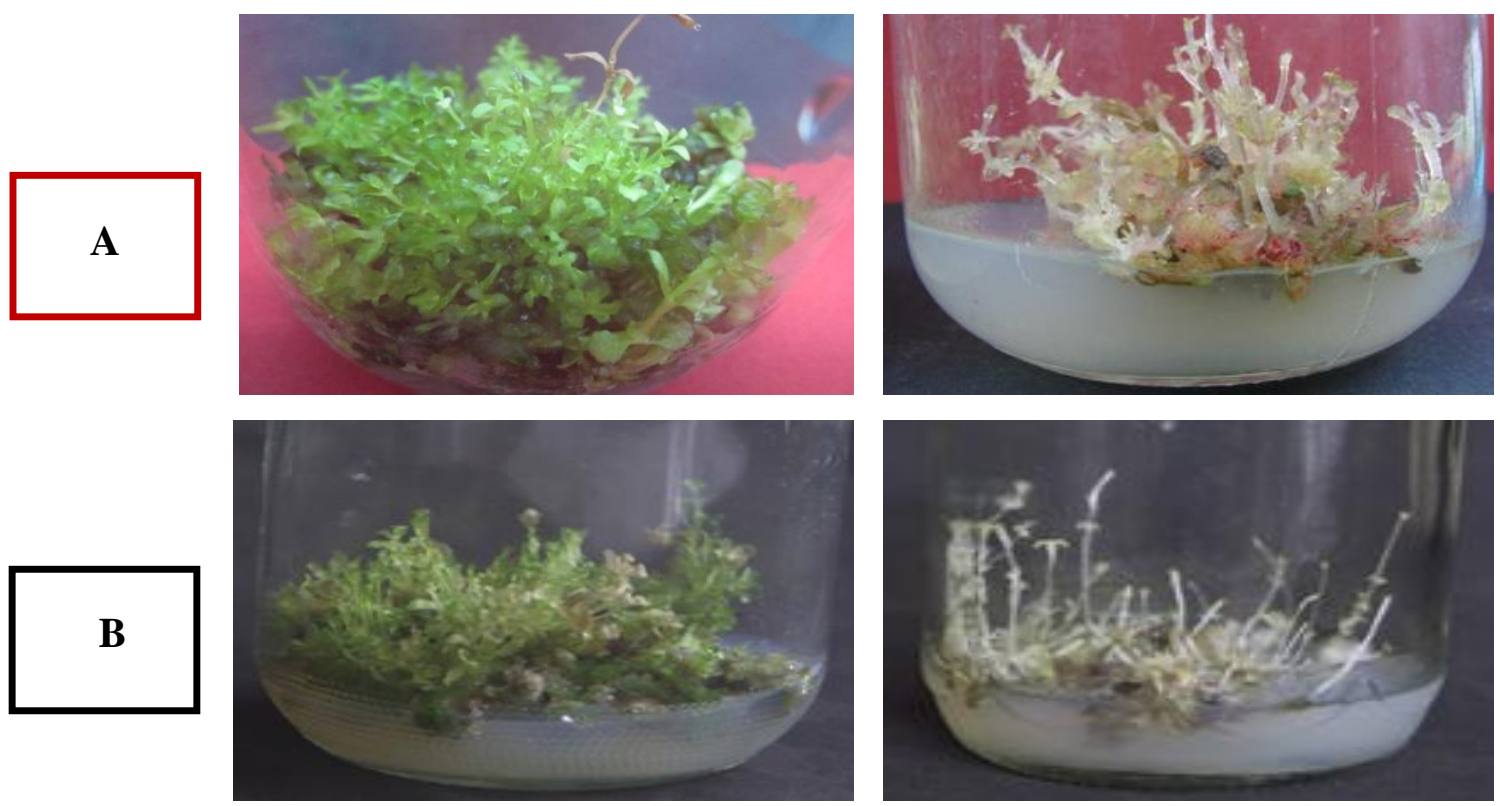

Fig.2 Effect of MS medium augmented with $0.1 \mathrm{mg} / \mathrm{l} \mathrm{NAA}$ plus $1 \mathrm{mg} / \mathrm{l} \mathrm{BA}$ on multiplication of nodal explants at light condition for 60 days (2 subcultures).

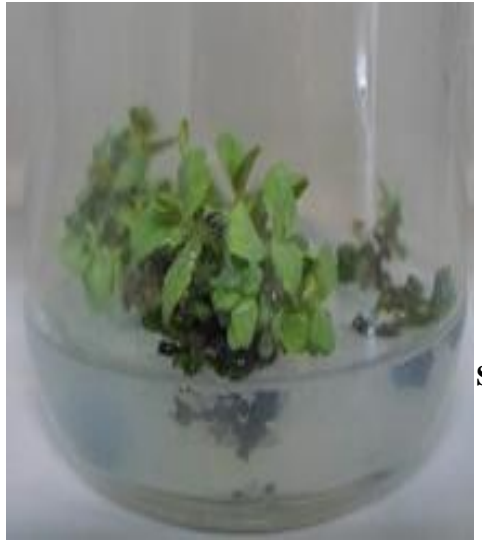

(Shootlets /cluster)
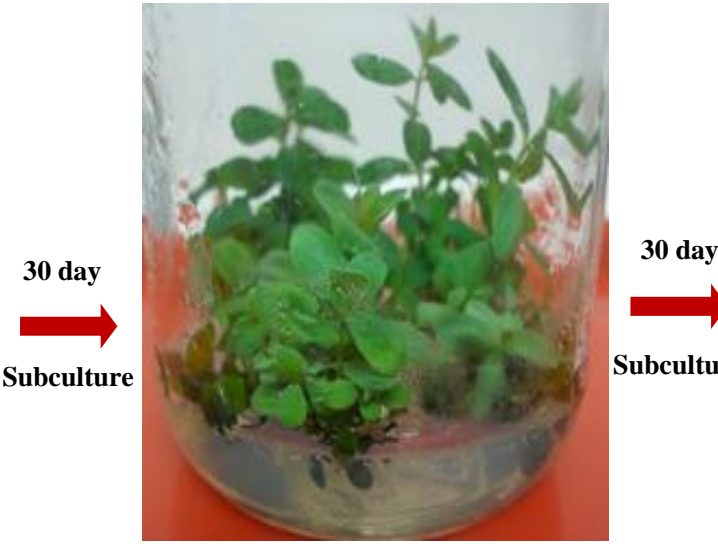

Subculture

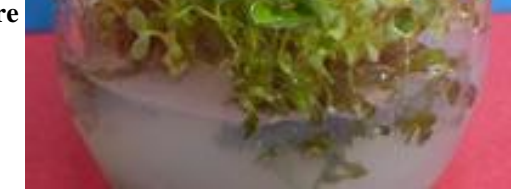

(Unexpected number of shoots) 
Fig.3 Roots formation/shoots cluster on MS media containing $5 \mathrm{mg} / \mathrm{l} \mathrm{IBA}$ under light condition.

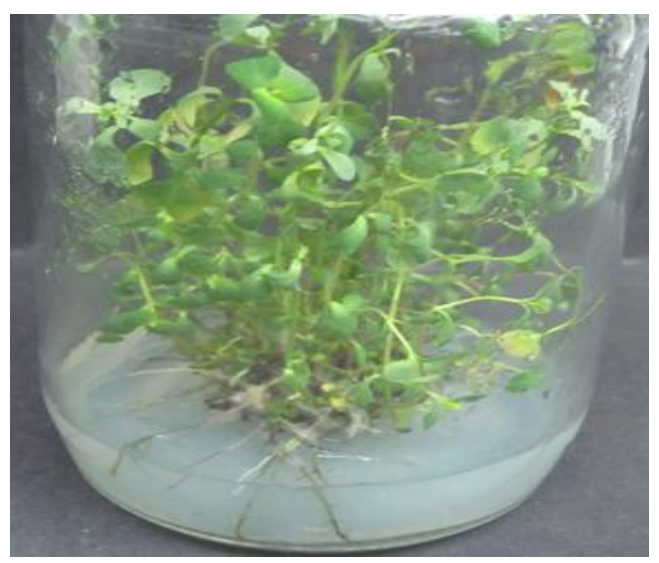

Fig.4 Growth rate (gm/day) of shoots derived from nodal segment and root explants during 5 weeks of cultivation.

\section{Growth rate (mg/day)}

- Nodal segment $\quad$ Root

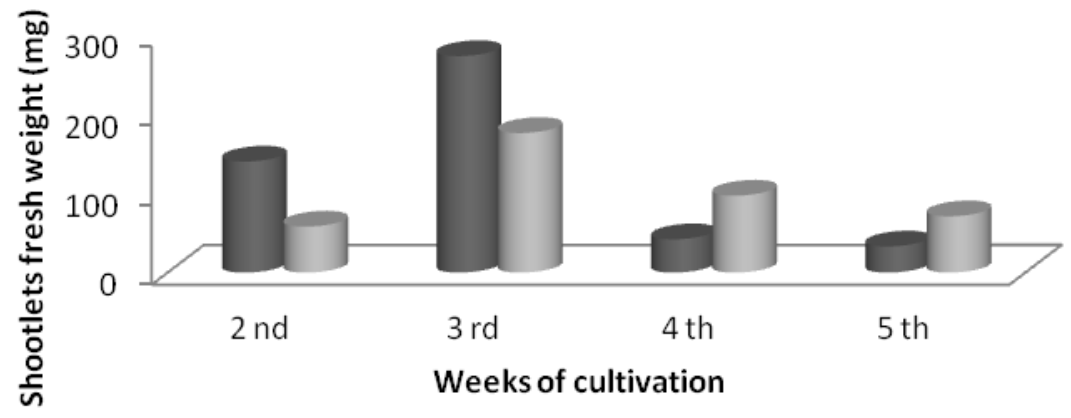

Fig.5 \& 6 Calibration curve of pure hypericin ; Hypericin standard curve
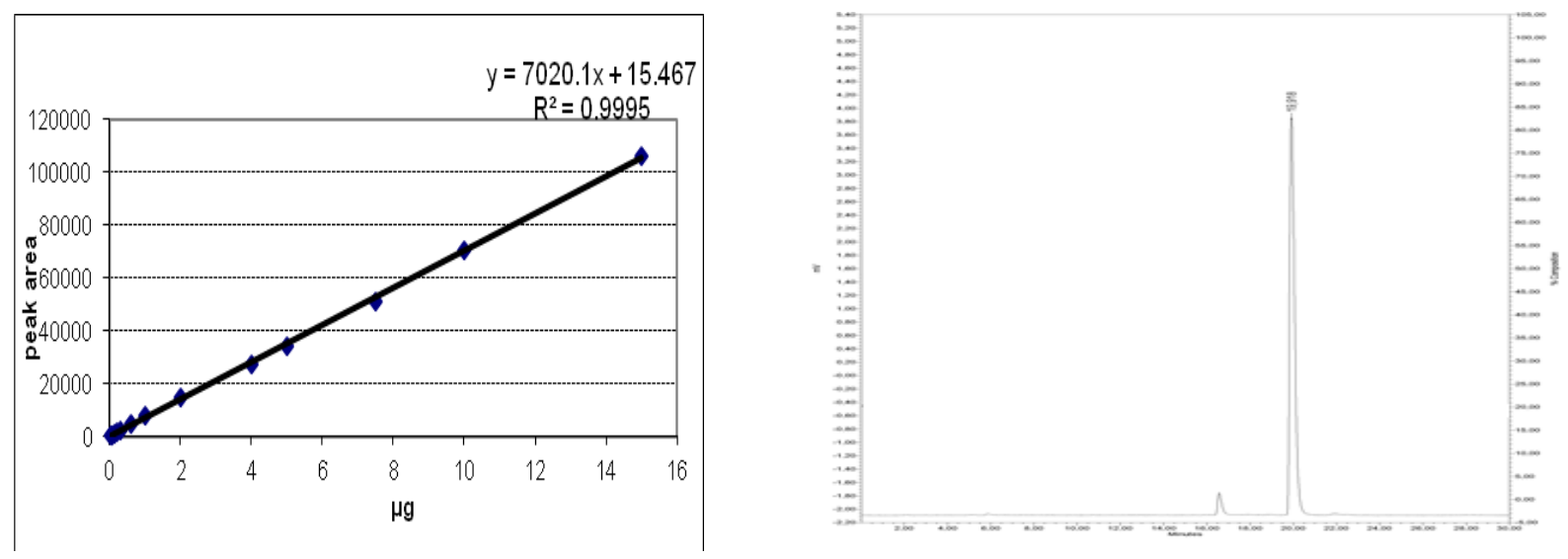
Fig.7 HPLC of hypericin extracted from indirect regenerated shootlets of nodal (A) and root explant (B) of H.sinaicum cultured on MS medium supplemented with $0.5 \mathrm{mg} / \mathrm{l} \mathrm{TDZ}$ and 0.05 $\mathrm{mg} / \mathrm{l} \mathrm{NAA}$ at light condition

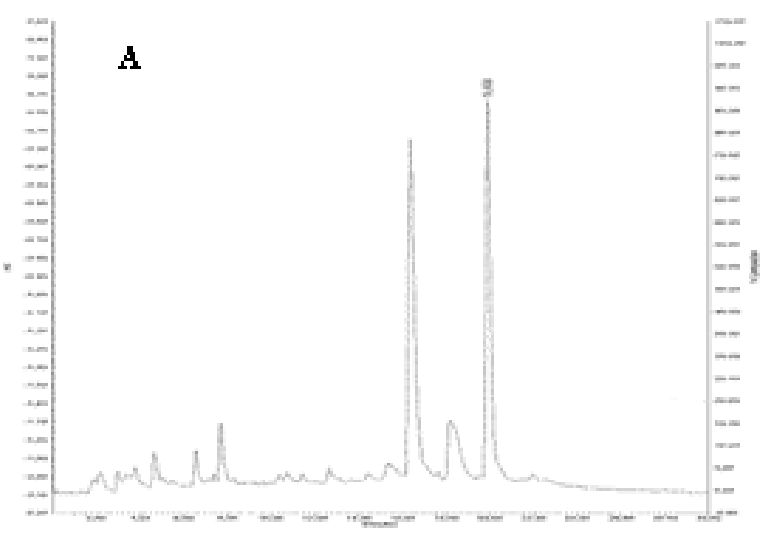

In vitro cell cultures cannot be maintained in for long periods in stationary phase. Cells begin to die and, as their contents enter the nutrient medium, death of the whole culture accelerates. Somewhat similar patterns of growth also occur in cultures of organized structures. These also cease growth and become moribund as the components of the medium become exhausted.

The previous study demonstrated that change in environmental factors could change of hypericin, total phenols, flavonoids and total protein synthesis in $H$. perforatum L. (Southwell and Bourke, 2001). The result showed more hypericin (84.70 and $72.18 \mu \mathrm{g} / \mathrm{g}$ dry weight) in indirect regenerates derived from nodal or root explants, respectively. Several report indicated that TDZ cause endogens changes in the levels of phytohormones and cell signaling and that maybe reason for more accumulation of hypericin content (Johnes $e t$ al.,, 2007). Our finding results matched with those of Santarem and Astaria (2003) who found that shoots and leaves derived in vitro plants which showed similar hypericin levels to those found in the leaves of the field-grown plants. They suggested that the accumulation of this compound is related to leaf differentiation. In addition, Karakaş et

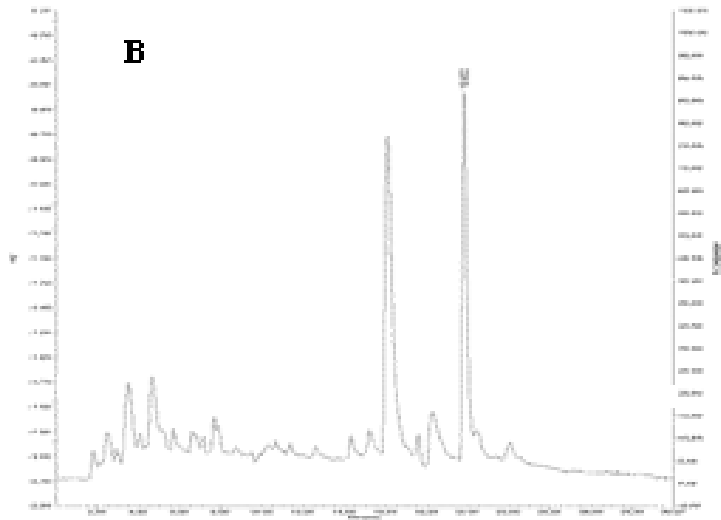

al., (2015) indicated that in vitro culture system can be improved for selection of plants with high levels of hypericin.

In conclusion, Hypericum sinaicum found only, In the Saint Catherine area in Egypt and listed as rare and endangered plant in Egyptian Pharmacopeia and there are not enough research on this plant although it contain several constituents such as naphthodianthrones (hypericin) and others compounds, which play an important role in diseases treatment for this reasons. Could be this study, is the first to establish a protocol for the successful indirect regeneration through callus and direct regeneration created from nodal and root explants of $H$. sinaicum which may provide more homogenous source of medicine. In addition, the regeneration protocol was used for multiplying of the plant and regenerated for commercial exploitation of target secondary metabolites especially hypericin compound. Hypericin that has been obtained by regeneration was determined by HPLC.

\section{Acknowledgement}

This research was supported by Science and Technology Development Fund (STDF) Egypt, ID: (82 \& 6548). 
Abbreviations: BA: Benzyladenine (6puine amino acid); Kin: Kinetin; 2,4-D: 2,4Dichlorophenoxyacetic acid; IAA: Indole-3acetic acid; NAA: 1-Naphthaleneacetic acid; IBA: Indole-3-butyric acid; TDZ: Thidiazuron; H. $\quad$ sinaicum:Hypericum sinaicum

\section{References}

Ayan, A.K., C. Çirak, K. Kevseroglu and Sokmen A. 2005. Effects of explants types and different concentrations of sucrose and phytohormones on plant regeneration and hypericin content in Hypericum perforatum L. Turk. J. Agric., 29: 197-204.

Bruni, R., and Sacchetti, G. 2009. Factors affecting polyphenol biosynthesis in wild and field grown St. John's Wort (Hypericum perforatum L. Hypericaceae/Guttiferae). Mol., 14: 682-725.

Butterweck, V. 2003. Mechanism of action of St John's wort in depression: what is known? CNS Drugs, 17: 539-562.

Carvalho, L.C., L. Goulao, C. Oliveria, J.C. Concalves and Amancio, S. 2004. RAPD assessment for identification of clonal identity and genetic stability of in vitro propagated chestnut hybrid, plant cell tissue organ cult. 77:23-27.

Coste, A., L. Vlase, A. Halmagyi, C. Deliu and Coldea, G. 2011. Effects of plant growth regulators and elicitors on production of secondary metabolites in shoot cultures of Hypericum hirsutum and Hypericum maculatum. Plant Cell Tiss. Organ Cult., 106: 279-288.

Debnath, S.C. 2005. Strawberry sepal: another explant for thidiazuron induced adventitious shoot regeneration. In Vitro Cell Dev. Biol. Plant, 41: 671-676.

Franklin, C., and Dias, A.C.P. 2005. Organogenesis and embryogenesis in several Hypericum perforatum genotype. In Vitro Cell Dev BiolPlant. 42: 321-330.

Franklin, G., and Dias A. C. P. 2006. Organogenesis and embryogenesis in several Hypericum perforatum genotypes. In Vitro cell Dev BiolPlant. 42:324-330.

Gamborg, O.L., R.A. Miller, and Ojima, O. 1968. Nutrient requirements of suspension cultures of soybean root cell. Exp. Cell Res., 50: 151-158.

George, E. F., M. A. Hall and De Klerk, G. 2008. Plant Propagation by Tissue Culture 3rd Edition. 205-226.

Johnes P.A.M., Z. Yi, S.J. Murch and Sazena P. K. 2007. TDZ induced regeneration of Echinacea Purpurea L. micropropagation in solid and liquid culture system, Plant Cell Rep., 26: 13-19.

Kakani, A., G. Li, and Peng, Z. 2009. Role of AUX1 in the control of organ identity during in vitro organogenesis and in mediating tissue specific auxin and cytokinin interaction in Arabidopsis. Planta, 229: 645-657.

Karakaş, Ö., H. Ç. Özen and Onay, A. 2015. Determination of hypericin content in callus and cell suspension cultures of Hypericum triquetrifolium Turra. Adv. Zool. Bot., 3(4): 184-189.

Karioti, A., Bilia, A.R. 2010. Hypericins as potential leads for new therapeutics. Int. J. Mol. Sci., 11: 562-594.

Khafagi, O., and Omar, K. 2012. Geographical Attributes Analysis for Egyptian Hypericum Sinaicum. Universal J. Environ. Res. Technol., 2(6): 500-514.

Kusari, S., S. Zühlke, J. Košuth, E. Čellárová and Spiteller, M. 2009. Light-independent metabolomics of endophytic Thielavia subthermophila provides insight into microbial hypericin biosynthesis. J. Nat. Prod., 72: 1825-1835. 
Lahlou, M. 2013.The Success of Natural Products in Drug Discovery. Pharmacology \& Pharmacy. 4:17-31.

Linsmaier, E.M., and Skoog, F. 1965. Organic growth factor requirements of Tobacco tissue cultures. Physiol. Plant, 18: 100-127.

Mederos, M.S. 1991. In vitro growth and multiplication of Hypericum canariense L. Acta Hortic., 289:133135.

Medina, M. A., B. Martínez-Poveda, M. I. Amores-Sánchez and Quesada, A. R. 2006. Hyperforin: More than an antidepressant bioactive compound? Life Sci., 79: 105-111.

Messina, B.A.M. 2006. Herbal Supplements: Facts and MythsTalking to Your Patients About Herbal Supplements. J. Peri Anesthesia Nursing, 21: 268-278.

Moura, M. 1998. Conservation of Hypericum foliosum, an endemic azorean species, by micropropagation. In Vitro Cell. Dev. Biol., Plant 34: 244-248.

Murashig, T., and Skoog, F. 1962. A revised medium for rapid growth and bioassay with tobacco tissue Cult. Plants Physiol., 15: 473-497.

Murch, S.J., K.L. Choffe, J.M.R. Victor, T.Y. Slimmon, S. KrishnaRaj, and Saxena, P.K. 2000. Thidiazuroninduced plant regeneration from hypocotyl cultures of St. John's wort (Hypericum perforatum. cv 'Anthos'). Plant Cell Rep., 19: 576-581.

Okigbo, R.N., C.L. Anuagasi1 and Amadi, J. E. 2009. Advances in selected medicinal and aromatic plants indigenous to Africa. J. Med. Plants Res., 3(2): 086-095.

Palmer, C.D., and Keller, W.A. 2011. Plant regeneration from petal explants of Hypericum perforatum L. Plant Cell Tiss. Organ Cult., 105:129-134.
Parrott, W.A., M.A. Bailey, R.E. Durham and Mathews, H.V. 1992. Tissue culture and regeneration in Legmes, in Biotechnology and crop improvement in Asia, edited by JP Moss (ICRISAT, Patancheru, India). 115-148.

Pasqua, G., P. Avato, B. Monacelli, A.R. Santamaria and Argentieri, M.P. 2003. Metabolites in cell suspension cultures, calli, and in vitro regenerated organs of Hypericum perforatum cv. Topas. Plant Sci., 165: 977-982.

Pretto, R., and Santarem E. R. 2000. Callus formation and regeneration from Hypericum perforatum leaves. Plant Cell Tiss. Org. Cult., 62: 107-113.

Ramachandra, S.R., and Ravishankar, G.A. 2002. Plant cell cultures: Chemical factories of secondary metabolites. Biotechnol. Adv., 20: 101-153.

Santarem, E.R., and Astaria, L.V. 2003. Multiple shoot formation in Hypericum perforatum L. and hypericin production, Braz J Plant Physol., 15: 43-47.

Skoog, F., and Miller, C.O. 1957. Chemical regulation of growth and organ formation in plant tissues cultured in vitro. Symp. Soc. Exp. Biol., 54:118130.

Southwell I.A., and Bourke, A.C. 2001. Seasonal variation in hypericin content of Hypericum perforatum L. (St. John's wort). Photochem., 56: 437441.

Taniguchi, S., Y. Imayoshi, E. Kobayashi, Y. Takamatsu, H. Ito, T. Hatano, H. Sakagaami, H. Tokuda, H. Nishino, D. Sugita and Yoshida, T. 2002. Production of bioactive triterpenes by Eriobotrya japonica calli. Phytochem., 59: 315-323.

Tripathi, L., and Tripathi, J. N. 2003. Role of biotechnology in medicinal plants, Trop. J. Pharm. Res., 2(2): 243-253.

Uzbay, T. I. 2008. Hypericum perforatum 
and substance dependence: a review. Phytother. Res., 22: 578-582.

Wojcik, A., and Podstolski, A. 2007. Leaf explant response in in vitro culture of St. John's wort (Hypericum perforatum L.). Acta Physiol. Plant, 29: 151-156.

Wu, X.Q., X.G.Li, and Zhang, X.S. 2008. Molecular analysis of hormoneregulated petal regeneration in Petunia. Plant Cell Rep., 27: 11691176.
Zobayed, S. M. A., and Saxena, P. K. 2003. In vitro-grown roots: a superior explant for prolific shoot regeneration of St John's Wort (Hypericum perfpratum L. cv. New Stem) in temparory immersion bioreactor. Plant Sci., 165: 463-470.

Zobayed, S.M.A., F. Afreen, E. Goto and Kozai, T. 2006. Plant environment interactions: accumulation of hypericin in dark glands of Hypericum perforatum. Annals of Bot., 98: 793804.

\section{How to cite this article:}

Heba D. Khlifa, Ibrahim A. Ibrahim, M. Bekhit, M. Szkop and H.S. Taha. 2016. Hypericum sinaicum L. in Vitro Regeneration and Analysis of Hypericin Content. Int.J.Curr.Microbiol.App.Sci. 5(8): 182-196. doi: http://dx.doi.org/10.20546/ijcmas.2016.508.020 